\title{
Pain in the immediate puerperium: nursing care contribution
}

A dor no puerpério imediato: contribuição do cuidado de enfermagem

El dolor en el puerperio inmediato: contribución del cuidado de enfermeira

\section{Juliana Vieira Figueiredo', Ana Virgínia de Melo Fialho', Glícia Mesquita Martiniano Mendonça', Dafne Paiva Rodrigues', Lúcia de Fátima da Silva'}

' Universidade Estadual do Ceará, Health Sciences Centre. Fortaleza, Ceará, Brazil.

\begin{abstract}
How to cite this article:
Figueiredo JV, Fialho AVM, Mendonça GMM, Rodrigues DP, Silva LF. Pain in the immediate puerperium: nursing care contribution. Rev Bras Enferm [Internet]. 2018;71(Suppl 3):1343-50. [Thematic Issue: Health of woman and child] DOI: http://dx.doi.org/10.1590/0034-7167-2017-0345
\end{abstract}

Submission: 05-21-2017

Approval: 09-18-2017

\section{ABSTRACT}

Objective: to analyze the contribution of clinical nursing care to the mother who has recently given birth with immediate postpartum pain based on the Kolcaba's Theory of Comfort. Method: qualitative study by the research-care method. Three nurses, who provided care for women in the immediate puerperium as caregiver-researchers and 30 postpartum women, were admitted to a public maternity hospital. A semi-structured interview was used for data collection, from which the thematic analysis of the content was carried out. Results: nursing care with influences from the biomedical model was observed, but it expresses concern when being cared for. It offers administration of medications, guidelines and non-pharmacological measures for pain relief. Final considerations: nursing care based on the Theory of Comfort contributed to pain relief in the immediate puerperium.

Descriptors: Ache; Postpartum Period; Nursing Care; Nursing Theory; Women's Health.

\section{RESUMO}

Objetivo: analisar a contribuição do cuidado clínico de enfermagem à puérpera com dor no pós-parto imediato, fundamentado na teoria do conforto de Kolcaba. Método: estudo qualitativo, pelo método de pesquisa-cuidado. Participaram três enfermeiras que prestam cuidados à mulher em puerpério imediato, como pesquisadoras-cuidadoras e 30 puérperas, no pós-parto imediato, internadas em uma maternidade pública. Utilizou-se entrevista semiestruturada para coleta de dados, dos quais procedeu-se a análise temática de conteúdo. Resultados: observou-se a realização de um cuidado de enfermagem com influências do modelo biomédico, porém, que expressa preocupação ao ser cuidado, oferece administração de medicações, orientações e medidas não farmacológicas para o alívio da dor. Considerações finais: o cuidado de enfermagem fundamentado na teoria do conforto contribuiu para alívio da dor no puerpério imediato.

Descritores: Dor; Período Pós-Parto; Cuidados de Enfermagem; Teoria de Enfermagem; Saúde da Mulher.

\section{RESUMEN}

Objetivo: analizar la contribución del cuidado clínico de enfermería a la puérpera con dolor en el posparto inmediato, fundamentado en la teoría del confort de Kolcaba. Método: estudio cualitativo, por el método de investigación-cuidado. Participaron tres enfermeras que prestan cuidados a la mujer en puerperio inmediato, como investigadoras-cuidadoras y 30 puérperas, en el posparto inmediato, internadas en una maternidad pública. Se utilizó entrevista semiestructurada para recolección de datos, de los cuales se procedió el análisis temático de contenido. Resultados: se observó la realización de un cuidado de enfermería con influencias del modelo biomédico, pero que expresa preocupación por el cuidado, ofrece administración de medicamentos, orientaciones y medidas no farmacológicas para el alivio del dolor. Consideraciones finales: el cuidado de enfermería fundamentado en la teoría del confort contribuyó para alivio del dolor en el puerperio inmediato.

Descriptores: Dolor; Período Post-Parto; Cuidados de Enfermería; Teoría de Enfermería; Salud de la Mujer. 


\section{INTRODUCTION}

Initial difficulties experienced by mothers who have recently given birth are related to the physical and physiological changes associated with pregnancy and childbirth, which may interfere with their quality of life $(\mathrm{QoL})^{(1)}$. The World Health Organization (WHO) in 1994 defined quality of life as "the individual's perception of their insertion in life in the context of the culture and value systems in which they live and in relation to their goals, expectations, standards and concerns"(2).

A Canadian study of 133 women in the immediate postpartum period found that in the first two weeks postpartum the most affected QoL dimensions of these women were physical capacity, energy level, and pain ${ }^{(3)}$.

This is a case study developed with mothers who have given birth recently, hospitalized at a reference hospital in humane childbirth in the city of Fortaleza, Ceará State. Nursing diagnoses that were more prevalent in the immediate puerperium were identified as activity intolerance, sleep deprivation, acute pain and impaired comfort ${ }^{(4)}$.

From the analysis of the mentioned studies, it is observed that the intervening factors of the QoL of mothers who have given birth recently, in the majority, are related to the lack of comfort. The state of comfort presupposes absence of worry, pain, suffering, among others, as a cause or effect of discomfort ${ }^{(5)}$

In this context, among the professionals of the health team, the nurse stands out as the one who assists the woman directly and individually during the puerperal period. Nursing focuses on the care of the human being in all life cycles to promote their health, comfort and QoL.

In this sense, it is justified the importance of identifying the comfort needs of women in the immediate puerperium, which will allow the planning and implementation of clinical nursing care actions with the objective of promoting mothers' comfort and contributing to the improvement of $\mathrm{QoL}$ in this period. Therefore, this study becomes relevant, since it will allow the analysis of the contribution of clinical nursing care to the puerperium.

\section{OBJECTIVE}

To analyze the contribution of clinical nursing care to the mother who has given birth recently with immediate postpartum pain, based on Kolcaba's Theory of Comfort.

\section{METHOD}

\section{Ethical aspects}

The research was conducted only after approval of the study by the Ethics and Research Committee of the State University of Ceará. This study is part of the thesis "Contribution of clinical nursing care to the mother who has given birth recently, based on Theory of Comfort" of the Post-Graduate Program in Clinical Care in Nursing and Health of the State University of Ceará (UECE).
The researcher-caregivers were identified by the acronym $\mathrm{RC}$ and the researcher-caregivers nurse by the acronym RCN, followed by the ordinal number in the order of participation in the study ( $\mathrm{RCN}-1, \mathrm{RCN}-2$ and $\mathrm{RCN}-3)$. Participating mothers who have given birth recently were referred to as surveyedcared and identified by the acronym SC followed by the ordinal number according to the order of insertion in the survey. This identification by acronym was adopted to guarantee the confidentiality and anonymity of the participants.

\section{Theoretical-methodological framework}

We chose the research-care method, as the methodological framework, for enabling the researcher to collect information about the phenomenon of study at the same time as care. There is an interaction between the researcher-caregiver and the surveyedcared, which is permeated by care, from the understanding of what is expressed by the surveyed in order to decide ways of caring that aim to reduce discomfort or improve the comfort ${ }^{(6)}$.

The Theory of Comfort was adopted as theoretical framework of this study. In this theory, comfort is a desirable result of nursing care, which is an immediate and holistic experience of being strengthened thanks to the satisfaction of its needs of relief, tranquility and transcendence in the physical, psychospiritual, environmental and sociocultural contexts ${ }^{(7)}$.

Relief is the state in which the patient has an attenuated discomfort. It refers to the satisfaction of a need by controlling global factors that generate discomfort, which can promote a state of calm or contentment, immediately. Tranquility is a state of calm or satisfaction, related to the satisfaction of specific needs, which cause discomfort or interfere with comfort. It is a more enduring and continuous state of contentment and well-being. Transcendence is understood as a condition in which one is above problems or one's own pain, as the highest level of comfort, from the satisfaction of needs of education and motivation, to enable the client to develop their potentials and adopt life habits to carry out their activities with maximum possible independence ${ }^{(7)}$.

Comfort is generated within the following contexts of human experience: physical - refers to bodily sensations and mechanisms of homeostasis; psycho-spiritual - refers to selfawareness, including esteem, identity, sexuality, and sense of life; sociocultural - related to interpersonal relations, family, society (finance, education), as well as family traditions, rituals, religious practices; environmental - relates to the external plane of human experience (temperature, light, sound, odor, color, furniture). In this perspective, pain is considered a comfort necessity in the physical context of the human experience, which requires nursing attention ${ }^{(7)}$.

In order to use the theory, it is proposed three moments: in the first, the nurse must identify the comfort needs of the mothers who have given birth recently and thus, plan and implement interventions to meet these needs, considering the intervening variables (factors not susceptible to change and over which they have little control) as fundamental to the success of interventions; in the second moment the activities promoting comfort are intensified and the mother who has given birth recently is prepared, consciously or unconsciously, to develop welfare seeking 
behaviors (health seeking behaviors), which may be internal (healing, immune function), external (health activities) or silent death; The third moment represents institutional integrity, when the institution and care team are ethically prepared to seek to improve the quality of services, including patient satisfaction, cost and morbidity reduction, and readmissions, as well as better policies and health practices. In this study the first two moments of the theory were developed ${ }^{(7)}$.

\section{Type of study}

It was carried out a research-care, study with a qualitative approach.

\section{Methodological procedures}

\section{Study scenario}

The study was conducted at a public maternity hospital in the municipality of Maracanaú, Ceará State. The researchcare scenarios were in a Rooming-in (RI), Natural Birth Center (NBC), Post-Anesthetic Care Unit (PACU) and Obstetric Emergencies $(\mathrm{OE})$, because they are places where hospitalization occurs and nursing care to women in the immediate postpartum period, at the research institution.

\section{Collection and data organization}

The steps of the research-care method were followed, namely: approximation with the phenomenon of the study; encounter with the surveyed-cared; establishment of research connections, care theory and practice; distance of researcher-caregiver and surveyed-cared and analysis of the apprehended $^{(6)}$.

The first step was to choose the qualitative methodology and the design of the research-care method, with the choice of the theoretical reference. In the second stage, the study scenario, the participants, the data collection technique and the ethical principles of the research were established ${ }^{(8)}$.

In the third stage, there was the establishment of research connections, theory and practice of care, interaction between researcher-caregiver and surveyed-cared, when the researcher-caregiver identifies, reveals what the researcher wants to research and at the same time observes, judges and decides with the surveyed-cared about the needs observed and perceived by both ${ }^{(6)}$. In the fourth stage it was necessary for the researcher-caregiver to prepare the surveyed-cared for the time of distance, as a necessary phase of the research, to begin the analysis of the data.

Three nurses participated as caregiver-researchers nurse, who were trained on the Theory of Comfort and the researchcare method. The inclusion criteria were: to be a nurse, to work in the institution for at least six months, considering it a minimum time to adapt the routines of work, and to assist the woman in the puerperal period, regardless of age.

In addition, 30 postpartum women were included in the study, according to inclusion criteria: women who were in the immediate puerperium ( 1 to 10 days postpartum) in that institution at the time of data collection, older than 18 years of age, regardless the type of childbirth or parity or the presence of clinical or obstetric intercurrences. Included in the study were those who were at least six hours after placental deceleration, as it was considered the necessary period for rest and minimal recovery after labor. Those with some mental disorder or communication difficulties that prevented participation in the research were excluded.

The data collection took place from December 2016 to February 2017, every day of the week, in the morning, afternoon and evening shifts, according to the scale of researchercaregivers nurse. The researcher responsible for this study participated with the help of three nurses who were members of the Research Group on Women's Health and Nursing (GRUPESME/UECE - CNPq), who were trained on the Theory of Comfort and the Research-Care Method, acting as researcher-caregivers in cooperation with the researcher-caregivers nurse in the care of the surveyed-cared, which made possible the presence of at least one researcher-caregiver in each research-care scenario.

Through the use of the research-care method, initially, the researcher-caregiver's perspective should be focused on the surveyed-cared and data collection. At first, it should be placed in the background, however, after finishing the process of care, the data are shown as the main figure ${ }^{(8)}$.

Thus, for data collection, a semi-structured interview script was used, which enabled the identification of comfort needs, the implementation of nursing care to mothers who have given birth recently and the verification of comfort after the care implemented. The first meeting between researcher-caregiver and surveyed-cared nurse was guided by the questions: Tell me, how do you feel physically? Is there something bothering you? Thus, through observation of comfort needs, the researcher-caregiver nurse implemented care for the mothers who have given birth recently and evaluated the results afterwards with the following questions: How are you now? Is there still something physically troubling you? Participant observation was also used as a data collection strategy, through which the researcher-caregiver enters the research scenario and, besides observing the phenomenon surveyed, participates in the experience as a continuous presence.

\section{Data analysis}

In the last stage, the analysis of the data seized in the light of the Theory of Comfort by the content thematic analysis $\operatorname{method}^{(9)}$, which enabled the elaboration of two categories: clinical nursing care for immediate postpartum pain relief; and relief of pain in the immediate puerperium.

\section{RESULTS}

\section{Clinical nursing care for immediate postpartum pain relief}

The actions of clinical nursing care to promote physical comfort were expressed more often by the verification of the medical prescription and administration of analgesic drugs according to the prescription.

[...] Complying with medical prescription. Analgesic has been given. (SC22-RCN2) 
[...] I enable analgesic according to medical prescription. (SC26- RCN1)

I checked the prescribed medications, and I noticed that the woman had taken paracetamol 5 hours ago. I explained that the medication can be retaken after 8 hours. I ask if the pain is tolerable or if she prefers to take another medicine. She says that can wait for the next time. (SC27-RC)

The use of non-pharmacological methods for pain relief was also evidenced as a measure for the physical comfort of mothers who have given birth recently.

I encourage walking but the patient continues to look discouraged. (SC10-RC)

To relieve pain and physical discomfort, RC checked for medical prescription of analgesic medication according to the need for SC and classification of pain. In the absence of prescription drugs, a medical-obstetric evaluation was requested for the prescription and administration of medications.

I checked the medical records that there was no medication prescribed for pain. I explained to the woman that headache might be associated with hunger. The mother who has given birth recently agreed. I told her that if she had a headache after lunch, she would ask for medical evaluation. Mother has agreed. (SC11-RC)

RCN 1 clarified the SC on the physiology of breastfeeding and its relationship to colic, and the willingness to care for and administer analgesics when necessary. In addition, it offered non-pharmacological measures for pain relief, such as the use of cold compress and the provision of information on the physiology of women in the puerperium.

I talk about the breastfeeding $x$ colic/oxytocin cycle. I inform if analgesic is necessary. I put myself at ease. (SC13-RCN1)

I guide on colic breastfeeding cycle. I asked for a prescription for an analgesic. Medicated according to what is prescribed. (SC15-RCN1)

Informed that there is medical prescription for pain, I offer. I am oriented on breastfeeding/colic cycle. (SC16-RCN1)

I provided medication according to medical prescription and according to level of pain. I informed about the breastfeeding and colic cycle. (SC19-RCN1)

She was medicated, oriented on breastfeeding $x$ oxytocin cycle. (SC21-RCN1)

I observe edema in the perineum and prescribe cold compress. Accomplished. (SC25-RCN1)

It was observed in this study that RC and RCN guided and assisted SC in the breastfeeding process, favoring the positioning and appropriate placement of the breast by the newborn, reducing nipple pain and promoting physical comfort in the immediate puerperium. In addition, they also advised on the treatment of nipple lesions.

I guide and assist during the correct positioning and placement of the newborn at the breast. I direct the importance of Exclusive Breastfeeding, mother and child benefits, free demand and care with nipple lesions, to moisturize with the milk itself and to position correctly when the NB grabs. (SC27-RC)

I examine breasts, hyperemic nipples. I direct the correct grab, breastfeeding and breast care. (SC24- RCN1)

I assist and guide the correct positioning and grab during breastfeeding to prevent nipple lesions and to the NB be fed properly. (SC28-RC)

Guidelines and assistance to the correct grab by positioning the NB near the breast. Benefits to mother and newborn from Exclusive Breastfeeding. Guidelines on the importance of Exclusive Breastfeeding and procedures for breastfeeding. (SC29-RC)

In this study, relief of nipple pain was observed as a need for SC. It is emphasized that this need, most of the time, is associated to the positioning of the newborn during breastfeeding and incorrect breastfeeding when only the nipple is carried out. Therefore, $\mathrm{RCN}$ and RC offered as a comfort measure guidance and help for the positioning and the appropriate grab of the newborn to the maternal breast.

During the visit I notice an uncomfortable patient [when breastfeeding], I help her to dress after bathing and I advise her to rest in bed. I advise her to remain at rest in the bed longer and help in the positioning of the newborn in the lateral decubitus position. (SC9-RC)

Breast pain may be associated with breast engorgement, closely related to failure to breastfeed, which may affect comfort of mothers who have given birth recently.

It was performed massage and milking of small amount of milk that was given to the NB. (SC23-RC)

Back pain was evidenced as an intervening factor of mothers who have given birth recently' comfort and may be associated with unsatisfactory bed posture.

I assist the patient to improve the positioning in the bed. I lifted the bedside $30^{\circ}$. It is advisable to place the NB in the crib when sleeping, to roam, to change positions during the day, to sit in the chair and to seek comfort when lying down to minimize the discomfort by correcting the posture. (SC5-RC)

\section{Relief of pain in the immediate puerperium}

Pain was the intervening factor of the most prevalent physical comfort of mothers who have given birth recently in the SC, soon after the implementation of actions of nursing clinical care to the SC, based on the Theory of Comfort. Pain relief was seen as an important contribution of this care in the immediate puerperium. 
[...] Discomfort is better. She feels relief with position change. (SC5-RC)

[...] She states that headache is over after some rest. (SC9-RC)

[...] Colic is over. (SC15-RCN1)

[...] I'm better and with less pain, because breasts are not hard anymore. (SC23-RC)

[...] She shows satisfaction and thanks the attention and care. (SC27-RC)

\section{DISCUSSION}

RCN expressed a care mode that values medical prescription, which may limit the possibilities of care and be related to the biomedical model, which has inspired the nursing schools. This model has influenced professional training, service organization and the production of health knowledge ${ }^{(10)}$.

We observed the implementation of non-pharmacological methods for pain relief, such as the stimulation of walking to favor peristaltic movements and elimination of intestinal gases. Constipation is a more common complaint in postpartum women who already had a history of chronic constipation, being exacerbated by late walking and inappropriate diet ${ }^{(11)}$. Therefore, walking should be encouraged as early as possible after childbirth, considering the state of maternal health, which favor satisfactory uterine involution, elimination of lochia, good functioning of the bladder and intestine, blood flow, reducing the risk of thrombosis ${ }^{(12)}$.

There were postpartum women with headache. This symptom may be associated with anesthesia for surgical delivery. Headache following spinal anesthesia usually develops 24 to 48 hours after anesthetic puncture, thus, the importance of informing mothers who have given birth recently about this complication and the need to seek treatment to avoid morbidity and associated mortality. Therefore, it is necessary for the anesthetist to be notified when the woman has a headache that does not improve with obstetric treatment ${ }^{(13)}$.

A cohort study conducted in four university hospitals in the United States and Europe aimed to identify predictors of headache during pregnancy in the immediate puerperium and after eight weeks of delivery. In this study, $3.7 \%$ of mothers who have given birth recently presented headache in the first 72 hours after delivery. Predictors were headache prior to gestation and use of regional spinal anesthesia for pain relief ${ }^{(14)}$.

From this perspective, there is a need for attention to the Guidelines for Care of Pregnant Women in C-section, and should only occur when there is a clinical indication. In Brazil, the rate of cesarean surgery is approximately $56 \%$, with considerable variation between public and private institutions. According to the World Health Organization (WHO), rates of cesarean surgery greater than $10 \%$ do not favor the reduction of maternal, perinatal or neonatal mortality ${ }^{(15)}$.

RCN guided the relationship between breastfeeding and the colic of mothers who have given birth recently. When the child suckles the mother's milk, oxytocin is released, a hormone that is produced by the posterior pituitary and acts by contracting the myoepithelial cells that cover the breast alveoli, favoring the ejection of the breast milk that is inside the alveoli ${ }^{(16)}$. This hormone also acts to stimulate uterine contractions, so when the newborn suckles the breast, a considerable increase in uterine activity may occur, which ends at the end of the feeding. This process is called the utero mammary reflex, characterized by stimulation of the nipples and the galactophore, which produces uterine contractions, which are referred by mothers who have given birth recently as colic ${ }^{(11)}$.

Another evidenced nursing care was the administration of a cold compress in the region of perineum. Randomized, controlled clinical trial was performed with 80 mothers in a maternity ward in the Brazilian Northeast and aimed to evaluate the clinical efficacy of cryotherapy for pain relief and to control perineum edema after vaginal delivery, which concluded that the use of cryotherapy was not effective to control pain and perineum edema after humanized vaginal delivery in women who had single gestation, full term delivery, and cephalic fetal presentation. In this study, women who underwent episiotomy, analgesia during labor, instrumental deliveries with forceps or vacuums, and those with active hemorrhage in the perineum or injury before delivery ${ }^{(17)}$ were excluded.

This result underscores the importance of the nurse to base her actions on effective scientific evidence, which requires clinical trials to evaluate the effectiveness of nursing care, which will enable an effective nursing care to reach the proposed results.

$\mathrm{RCN}$ and RC implemented care for nipple pain relief. The presence of pain in the nipple is a factor that causes discomfort in the immediate puerperium. Nipple lesion is an important complication related to breastfeeding that causes great discomfort in the mother who has given birth recently and can contribute to early weaning, requiring nursing intervention and care.

The main cause of pain during breastfeeding is the presence of nipple lesions, which are associated with unsatisfactory positioning and handling. Other factors may also be related, such as the presence of flat or inverted nipples, oral defects in the child, prolonged non-nutritive sucking by the child, improper use of milk withdrawal pumps, inappropriate interruption of the child's suction when removal of the breast, use of creams and oils on the nipples, use of intermediate nipple protectors and continuous exposure to moisture ${ }^{(16)}$.

A study carried out in the city of Santo André, São Paulo State, Brazil, with 29 mothers who have given birth recently observed that $44.0 \%$ had nipple lesions in the puerperal pe$\operatorname{riod}^{(18)}$. It is perceived that this is a common complication in the puerperium, which requires attention of the nursing team.

Research has shown that the main cause of maternal anxiety and suffering was nipple trauma, which may lead to a decrease in the frequency of breastfeeding. This complication may be related to the lack of access to information and social and professional support in the mothers who have given birth recently' pregnancy cycle ${ }^{(19)}$.

A cross-sectional survey of 80 mothers who have given birth recently who were in AC of a maternity hospital in Porto Alegre city showed that $36.3 \%$ of them reported difficulties during the first 12 to 48 hours of breastfeeding. $69 \%$ of the 
complaints were related to the newborn's hand (27.6\%), breast pain $(27.6 \%)$ and breast lesions (13.8\%). Primiparous women presented more complaints $(50 \%)$ than those with more than one child $(21.1 \%)^{(20)}$

It is observed the need of attention of the nurse and her team, who assist the woman in the immediate puerperium, offering a preventive attention to the appearance of these complications associated with breastfeeding, through observation of the difficulties experienced by mothers who have given birth recently in the first hours after the birth, correcting the inadequacies and stimulating the appropriate aspects.

When the nipple lesion is already present, the nurse can act to relieve pain and promote comfort of mothers who have given birth recently by directing them to begin breastfeeding for the less affected breast; before beginning the feeding, to milk a little milk, necessary to stimulate the milk ejection reflex, which will cause the child to suck the breast with less force; encourage varied positions to breastfeed, reducing pressure on injured and painful areas; use of protection between feedings, which must have holes to allow ventilation and be positioned between the clothing and the breast; to guide the use of systemic analgesics orally, when mothers who have given birth recently refer to severe pain ${ }^{(16)}$.

This study aimed to identify the main difficulties related to breastfeeding and to identify which breastfeeding interventions, demanded by mothers who have given birth recently attended at a gynecology and obstetrical clinic, in a municipality in the South region of Brazil, showed that $93.5 \%$ of women in $(p<0.05)$. In the present study, the presence of breastfeeding during the first 10 days presented difficulty in breastfeeding during the first 10 days, $80.5 \%$ reported difficulty during breastfeeding, $38.5 \%$ had nipple lesion and $45 \%$ breast engorgement.

When breast engorgement occurs and the breast becomes very full, the areola may become firm, which makes it difficult to grab. On that occasion, it is recommended to manually milk a little milk to make the grab easier ${ }^{(16)}$.

In the puerperium, the woman experiences many difficulties related to breastfeeding, especially the nipple lesions, the correct positioning of the baby, the appropriate breast pocket and breast engorgement. Therefore, it is necessary that the nurse supports, encourages and helps in this process so that breastfeeding occurs in a satisfactory way for mother and child ${ }^{(22)}$.

The breastfeeding process needs to be learned by the mother who has given birth recently and the newborn. To achieve a good breast lift, the baby needs to open his mouth wide and not only the nipple, but also part of the areola, which will allow the formation of the vacuum, so that the nipple and the areola remain inside the mouth during breastfeeding. In addition, an incorrect grab can damage the nipples, producing nipple lesions ${ }^{(16)}$.

In this perspective, there is a need for guidelines to mothers who have given birth recently on effective breastfeeding, contributing to the prevention of breast complications and treatment of these complications when they are already present.

Health education is an intrinsic practice for nursing care in different care scenarios, with emphasis on the care of mothers who have given birth recently. In this practice, more attention is paid to the topics of caring for the woman after childbirth, feeding, bathing of the newborn and breastfeeding ${ }^{(23)}$.

This study observed that health care professionals attending women in RI offer guidance on the importance of breastfeeding, positioning and correct delivery of the breast by the newborn ${ }^{(12)}$.

For correct positioning of the baby and a good breastfeed during breastfeeding, the Ministry of Health ${ }^{(16)}$ recommends that the breasts be completely exposed when possible and the baby should have his or her arms free; the mother needs is in a very comfortable position; the body of the baby should be facing the mother's, the belly with the belly; baby's body and head need to be aligned, buttocks well supported; the baby's lower arm should be free; the mother should hold the breast allowing the areola to be free for the baby's grab; the baby's chin touches the breast; the baby's nostrils remain free; baby's lips need to be turned out.

To identify whether the baby is satisfactorily performing the breastfeed during breastfeeding, the nurse may check for signs of an inappropriate placement, such as: newborn cheeks hollowed during sucking; noise produced by the language; breast with stretched or deformed appearance during breastfeeding; nipples with red streaks or whitish or flattened regions when baby releases breast; presence of pain during breastfeeding ${ }^{(16)}$.

This research aimed to identify the pain sites related to the practice of breastfeeding in the immediate puerperium and to provide information about the benefits and postures appropriate to breastfeeding; was performed in a maternity hospital in the city of Belém, Pará State, Brazil, with 120 mothers who have given birth recently and showed that $75 \%$ referred to discomfort during breastfeeding. The sites of discomfort during breastfeeding, in $50 \%$ of the mothers, were the cervical and lumbar region ${ }^{(24)}$.

Back pain, usually in the lower back, may be related to poor positioning of the woman in the bed, often due to the presence of her newborn in the bed, compromising proper positioning and comfort of mothers who have given birth recently. It is common the observation of mothers who put their newborns in their bed, which in addition to impairing the positioning and the mother's rest, represents a risk factor for falls and asphyxia of the newborn. In this scenario, the presence of the nurse is essential to identify the risks and to prevent the health related injuries of the mother and child binomial.

This study aimed to evaluate the prevalence of postural changes in postpartum women during breastfeeding; was performed at the Regional Hospital of Cajazeiras/PB and identified that $60 \%$ of the participants reported that during breastfeeding there were positions that generated discomfort. $53.3 \%$ of the mothers positioned their child in an inclined manner, and hyperkyphosis was observed in $66.7 \%$ of the participants ${ }^{(25)}$. It is noticed that these postural alterations added to poor positioning of the mother who has given birth recently in the bed during the rest periods can contribute to the appearance of back pain.

It was evidenced in this study that the implementation of actions of clinical nursing care to mothers who have given birth recently based on the Theory of Comfort, contributed to relief of pain in the immediate puerperium. 


\section{Study limitations}

As a limitation of this study, the small number of nurses who accepted to participate and the absence of nurses in the $\mathrm{RI}$ sector as RCN were perceived as a limitation of this study. Although the invitation to participate in the research was extended to all nurses in the maternity ward, no nurse from the $\mathrm{RI}$ unit accepted to participate. Therefore, it is considered the need for new strategies to encourage the participation of nurses in research that favors the scientific growth of nursing and the improvement of care in the puerperium.

\section{Contributions to the Nursing}

This study made it possible to demonstrate the accomplishment of a nursing care that contributes to the improvement of comfort in the immediate puerperium by the relief of mothers who have given birth recently' pain. It was observed that the use of comfort theory as a subsidy for this care favored the achievement of results. The use of the research-care method is a methodological tool that allowed the RCN and RC to provide timely care for the needs of the SC at the same time as researching.

\section{FINAL CONSIDERATIONS}

Based on this study, it was possible to highlight the contribution of nursing care based on the Theory of Comfort to women in the immediate puerperium. It was identified a way of care still influenced by the biomedical model of health care, however, with characteristics that indicate a practice of singular care that is concerned with the needs of mothers who have given birth recently.

The RCN and RC carried out guidelines on the physiology of the puerperium and the relationship of colic to breastfeeding, positioning and appropriate placement of the newborn to the breast during breastfeeding, prevention and treatment of nipple lesion and breast engorgement, always expressing disposition to help and promote comfort to mothers who have given birth recently.

Considering the results presented, it is recommended to adopt the comfort theory as a subsidy for the care of nurses who have given birth recently who assist this population, in the different scenarios. It is suggested to carry out new studies that use this theory with other populations, which may contribute to a better visualization of the applicability of this theory in nursing care.

\section{REFERENCES}

1. Lima-Lara AC, Fernandes RAQ. Quality of life in the mediate puerperium: a quantitative study. O Braz J Nurs[Internet]. 2010[cited 2017 May 8];9(1). Available from: http://www.objnursing.uff.br/index.php/nursing/article/view/2815

2. Group W. The World Health Organization Quality of Life Assessment (WHOQOL): position paper from the World Health Organization. Social Sci Med[Internet] 1995 [cited 2017 May 8];41(10):1403-9. Available from: http://www.sciencedirect.com/ science/article/pii/027795369500112K?via\%3Dihub

3. Baghirzada L, Downey KN, Macarthur AJ. Assessment of quality of life indicators in the postpartum period. Int J Obstet Anesth[Internet]. 2013 [cited 2017 May 8];22(3):209-16. Available from: http://linkinghub.elsevier.com/retrieve/pii/S0959-289X(13)00039-3

4. Barbosa EMG, Oliveira FDM, Guedes MVC, Monteiro ARM, Rodrigues DP, Silva LF, et al. Nursing care for one puerpera based on the theory of comfort. Rev Min Enferm[Internet]. 2014 [cited 2017 May 8];18(4):845-9. Available from: http://pesquisa.bvs.br/ aps/resource/pt/lil-754355

5. Kolcaba KY, Kolcaba RJ. An analysis of the concept of comfort. J Adv Nurs[Internet]. 1991 [cited 2017 May 8];16(11):1301-10. Available from: https://www.ncbi.nlm.nih.gov/pubmed/1753026

6. Neves EP, Zagonel IPS. Pesquisa-cuidado: uma abordagem metodológica que integra pesquisa, teoria e prática em enfermagem. Cogitare Enferm[Internet]. 2006 [cited 2017 May 8];11(1):73-9. Available from: http://revistas.ufpr.br/cogitare/article/view/5980

7. Kolcaba K. Comfort theory and practice: a vision for holistic health care and research. New York: Springer Publishing Company; 2003.

8. Zagonel IPS, Neves EP, Marques KMAP, lamin SRS, Victor LS. Pesquisa cuidado: da teoria à prática. In: Lacerda MR, Costenaro RGS, (Eds.). Metodologias da pesquisa para a enfermagem e saúde: da teoria à prática. Porto Alegre: Moriá; 2015. p. 215-49.

9. Bardin L. Análise de conteúdo. São Paulo: Edições 70; 2011.

10. Fertonani HP, Pires DEP, Biff D, Scherer MDA. Modelo assistencial em saúde: conceitos e desafios para a atenção básica brasileira. Ciênc Saúde Colet[Internet]. 2015 [cited 2017 May 8];20(6):1869-78. Available from: http://www.scielosp.org/pdf/csc/v20n6/14138123-csc-20-06-1869.pdf

11. Montenegro CAB, Rezende Filho J. Rezende obstetrícia fundamental. 13th ed. Rio de Janeiro: Guanabara Koogan; 2014.

12. Rodrigues DP, Dodou HD, Lago PN, Mesquita NS, Melo LPT, Souza AAS. Care for both mother and child immediately after childbirth: a descriptive study. O Braz J Nurs[Internet]. 2014 [cited 2015 Oct 3];13(2):227-38. Available from: http://www. objnursing.uff.br/index.php/nursing/article/view/4231

13. Sachs A, Smiley R. Post-dural puncture headache: the worst common complication in obstetric anesthesia. Sem Perinatol[Internet]. 2014 [cited 2017 Apr 20];38:386-94. Available from: http://www.sciencedirect.com/science/article/pii/S0146000514000809

14. Tuner DP, Smitherman TA, Eisenach JC, Penzien DB, Houle TT. Predictors of headache before, during, and after pregnancy: a 
cohort study. Headache[Internet]. 2012[cited 2017 Apr 21];52(3):348-63. Available from: https://www.ncbi.nlm.nih.gov/pmc/ articles/PMC3299832/

15. Comissão Nacional de Incorporação de Tecnologias no SUS. Diretriz Nacional de Assistência ao Parto Normal: relatório de recomendação [Internet]. Secretaria de Ciência, Tecnologia e Insumos Estratégicos. Brasília: Ministério da Saúde; 2016 [cited 2017 Apr 21]. Available from: http://conitec.gov.br/images/Consultas/2016/Relatorio_Diretriz-PartoNormal_CP.pdf

16. Brasil. Ministério da Saúde. Secretaria de Atenção à Saúde. Departamento de Atenção Básica. Saúde da criança: aleitamento materno e alimentação complementar [Internet]. Caderno de Atenção Básica - № 23. Brasília: Ministério da Saúde; 2015[cited 2017 Apr 21]. Available from: http://bvsms.saude.gov.br/bvs/publicacoes/saude_crianca_aleitamento_materno_cab23.pdf

17. Morais I, Lemos A, Katz L, Melo LFR, Maciel MM, Amorim MMR. Perineal pain management with cryotherapy after vaginal delivery: a randomized clinical trial. Rev Bras Ginecol Obstet[Internet]. 2016 [cited 2017 Apr 14];38(7):325-32. Available from: http://www.scielo.br/pdf/rbgo/v38n7/0100-7203-rbgo-38-07-00325.pdf

18. Aparecida KRM, Chaves LC, Filipini R, Fernandes IC. Percepção das mães em relação ao aleitamento materno no período do pósparto. ABCS Health Sci[Internet]. 2014 [cited 2017 Apr 21];39(3):146-52. Available from: https://www.portalnepas.org.br/abcshs/ article/view/648/647

19. Amaral LJX, Sales SS, Carvalho DPSRP, Cruz GKP, Azevedo IC, Ferreira Jr MA. Fatores que influenciam na interrupção do aleitamento materno exclusivo em nutrizes. Rev Gaúcha Enferm[Internet]. 2015 [cited 2017 Apr 20];36:127-34. Available from: http://www.scielo.br/pdf/rgenf/v36nspe/0102-6933-rgenf-36-spe-0127.pdf

20. Castelli CTR, Maahs MAP, Almeida ST. Identificação das dúvidas e dificuldades de gestantes e puérperas em relação ao aleitamento materno. Rev CEFAC[Internet]. 2014[cited 2017 Apr 18];16(4):1178-86. Available from: http://www.scielo.br/pdf/rcefac/v16n4/ en_1982-0216-rcefac-16-4-1178.pdf

21. Moreno PFBB, Schmidt KT. Aleitamento materno e fatores relacionados ao desmame precoce. Cogitare Enferm [Internet]. 2014[cited 2017 Apr 14];19(3):576-81. Available from: http://revistas.ufpr.br/cogitare/article/view/32366/23249

22. Porto SL, Sebold LF, Kempfer SS, Girondi JBR. O apoio da enfermagem nos conhecimentos e nas dificuldades do processo da amamentação. Rev Iberoam Educ Invest Enferm[Internet]. 2013[cited 2017 May 8];3(3):21-28. Available from: http://www. enfermeria21.com/revistas/aladefe/articulo/77/

23. Cassiano NA, Holanda CSM, Costa RKS, Morais FRR, Maranhão TMO. Nursing care to woman in immediate puerperium: a narrative description. J Res: Fundam Care[Internet]. 2015[cited 2017 Mar 10];7(1):2061-71. Available from: http://www.seer. unirio.br/index.php/cuidadofundamental/article/view/3675

24. Menezes LSH, Gomes RMSB, Lima BO, Sousa EX. Dor relacionada à prática da amamentação no puerpério imediato. Fisioter Brasil. 2014;15(2):100-5.

25. Falcão KPM, Carvalho ACF, Marques ACML, Vieira AG, Barros JD, Rolim RB. Prevalence of postural changes on puerperals before breastfeeding position. J Nurs UFPE[Internet]. 2015 [cited 2017 Apr 17];9(1):9839-45. Available from: https://periodicos.ufpe.br/ revistas/revistaenfermagem/article/view/10776/11918 